http://journal.uinsgd.ac.id/index.php/biodjati

\title{
THE EFFECT OF COFFEE FRUIT SKIN EXTRACT ON SPERM CHARACTERISTICS AND TESTICULAR OF MICE WITH ETHANOL-INDUCED
}

\author{
Haris Setiawan ${ }^{1 *}$, Rita Maliza ${ }^{2}$, Syaiful Adam Maulana ${ }^{3}$, Muhammad Ilham Hisbullah ${ }^{4}$
}

Received : August 11, 2020

Accepted : October 25, 2020

DOI: 10.15575/biodjati.v5i2.9280

1,2,3,4 Laboratory of Animal Structure and Physiology, Program Study of Biology, Faculty of Applied Science and Technology, Universitas Ahmad Dahlan, Jl. Ringroad Selatan, Tamanan, Kec. Banguntapan, Bantul, DIY Yogyakarta, (0274) 511830

e-mail:

*1haris.setiawan@bio.uad.ac.id ²ritamaliza@bio.uad.ac.id

3ohsyailana@gmail.com

Ilhamwae21@gmail.com

*Corresponding author

Abstract. Coffee fruit skin contains antioxidant compounds that can repair damaged tissues, especially those of reproductive organs. This study was designed to assess to what extent the methanolic extract of coffee fruit skin affected sperm characteristics and testicular histology in mice receiving 15\% ethanol for 15 days. It used 25 male mice aged four months and employed a completely randomized design with two controls $(K)$ and three treatments $(P)$, namely $K 1$ (without ethanol), K2 (15\% ethanol), P1 (15\% ethanol and the methanolic extract of coffee fruit skin, or MECS, at $125 \mathrm{mg} /$ $\mathrm{kg} \mathrm{BW}), P 2$ (15\% ethanol and MECS $250 \mathrm{mg} / \mathrm{kg} \mathrm{BW})$, and P3 (15\% ethanol and MECS $500 \mathrm{mg} / \mathrm{kg} \mathrm{BW}$ ). These treatments were administered orally with a $1 \mathrm{~mL}$ disposable syringe for 15 days. The parameters observed were sperm characteristics (viability, morphology, and sperm count) and the microscopic structure of the testicles (lumen area, diameter, and area of seminiferous tubules). These data were then analyzed using the one-way ANOVA, continued with the LSD and Duncan's tests $(P<0.05)$. The results showed that P2 (250 $\mathrm{mg} / \mathrm{kg} \mathrm{BW})$ substantially improved sperm count $\left(86.5 \times 10^{5} \pm 1.73\right.$ cells/ $m L)$, sperm viability $(87.26 \pm 0.05 \%)$, and the proportion of normal sperm morphology (93.33 $\pm 0.004 \%)$ of mice with $15 \%$ ethanol-induced sperm damages. Testicular histology also confirmed improvements in spermatogenic cells, as evident from the lumen, diameter, and area seminiferous tubules after receiving $P 1$ and $P 2$. In conclusion, the optimum dose of the coffee skin extract for improving sperm quality and microscopic structures of mice testicles is $250 \mathrm{mg} / \mathrm{kg} \mathrm{BW}$.

Keywords: coffee skin extract, ethanol, reproductive system, sperm characteristics, testicular histology

\section{Citation}

Setiawan, H., Maliza, R., Maulana, S. A. \& Hisbullah, M. I. (2020). The Effect of Coffee Fruit Skin Extract on Sperm Characteristics and Testicular of Mice with Ethanol-Induced. Jurnal Biodjati, 5(2), 259-270.

\section{INTRODUCTION}

Infertility, a condition where the reproductive system fails to achieve a clinical pregnancy, is a serious problem that many men worldwide have to face (Parhizkar et al., 2013). Various types of toxic compounds that harm fertility are consumed by the public, including beverages that contain ethanol (alcohol). Pre-clinical and clinical studies have 


\section{JURNAL BIDDJATI}

http://journal.uinsgd.ac.id/index.php/biodjati

proven that ethanol can reduce fertility in men and women (Condorelli et al., 2015). Research showed that ethanol consumption impacts sperm function that related to sex hormone levels and the tubular function of the testis (Condorelli et al., 2015). Moreover, ethanol induces abortion, hinders the process of pregnancy, and triggers congenital anomalies in the fetus (Cohen et al, 2003). In male reproductive organs, this compound can lower the concentration of steroid hormones, interfering with the process of spermatogenesis and causing tissue damage in testicles and epididymis (De Souza et al., 2017).

Ethanol may significantly be contributing factors to male infertility which is caused by decreased reproductive hormone and semen parameters (Mathur et al., 2019). Wael \& Mahulette (2013) explained that once alcohol (ethanols) enters the body, it is metabolized into acetic acid with the help of an enzyme called alcohol dehydrogenase (ADH) and induces an oxidation process. Then, ethanol-derived acetaldehyde will activate cytochrome P450s enzymes, which play a role in the formation of Reactive Oxygen Species (ROS). Elevated levels of ROS potentially alter the integrity of sperm membranes and induce deleterious effects on sperm quality and function. Human bodies can inhibit ROS activities by consuming food or supplements that contain antioxidants.

Antioxidants are compounds functioning to prevent structural damages of a cell due to oxidation (Dungira et al., 2012). Apart from improving sperm quality, they also protect sperm quality from toxic compounds (spermatoprotective properties). One of the safest sources of consumable antioxidants is herbal ingredients. Lycopene is an example of antioxidants found in herbal plants and has been reported to protect sperm morphology from oxidative stress and prevent histo- pathological damage of testicles (Çeribaşi et al., 2010). Antioxidants in the form of vitamin E can alleviate cytotoxicity in cells and, therefore, improve sperm quality (Meriani, 2017). In the tropics, there are various types of herbal plants known for their antioxidant constituents, among which are the abundant yet untapped skin of coffee fruit.

Coffee fruit is a commodity plant cultivated in tropical countries, such as Robusta dan Arabica. Coffee production is currently not complemented with broad utilization of the waste produced, coffee fruit skin. Coffee fruit skin (mesocarp) has high antioxidant compounds. It contains secondary metabolites of polyphenols, such as tannins, flavonoids, hydroxycinnamic acids, and caffeine (Esquivel \& Jiminez, 2012). These natural antioxidants are expected to repair cell damage due to elevated concentrations of ROS induced by toxic compounds. Such an effect is also expected to occur in damaged reproductive organs that determine sperm quality. Accordingly, research focusing on the benefits of coffee fruit skin extract and its contents as natural antioxidant agents becomes necessary. This study was designed to observe the effects of feeding Arabica Coffee fruit skin extract to mice with ethanol-induced poor sperm quality and histopathological damage of testicles for 15 days.

\section{MATERIALS AND METHODS}

\section{Methanolic Extracts of Coffee Fruit Skin}

This research was conducted at the Laboratory of Animal Structure and Physiology Universitas Ahmad Dahlan in October 2019 - July 2020. Arabica coffee fruit skin (exocarp and mesocarp) was placed under direct sunlight to produce dried medicinal ingredients. Afterward, the dried skin was ground into powder, weighed using analytical scales 


\section{JURNAL BIDDJATI}

http://journal.uinsgd.ac.id/index.php/biodjati

(2 kg), and extracted with $96 \%$ methanol at $55-60^{\circ} \mathrm{C}$ for 36 hours in a Soxhlet extractor to create a liquid extract. The liquid extract was evaporated to remove the methanol solvents in a rotary evaporator at a temperature of $60^{\circ} \mathrm{C}$ for 3 hours until a thick extract weighting $107.273 \mathrm{~g}$ was formed. A phytochemical screening, including saponins, tannins, alkaloids, and phenolics detection tests, was carried out to determine the antioxidant content of the extract.

\section{Acclimatization of Test Animals}

Twenty-five Male Balb/C mice (34-38 gr in weight, 4 month old) were placed in a cage set at a temperature of $22 \pm 3^{\circ} \mathrm{C}$, a relative humidity of 30-37 RH, and a 12-hour light/12hour dark cycle and allowed access to food and drinking water according to standards (ad-libitum). The cage was made of water-resistant material with the following dimension: $77.4 \mathrm{~cm}^{2}$ in area and $12.7 \mathrm{~cm}$ in height. Mice were acclimatized for six days, and the ones that met the criteria were clustered randomly into five groups.

\section{Rearing and Treatment of Test Animals}

This study used five different treatments with 5 replication in each: K1 (without $15 \%$ ethanol), K2 ( $0.5 \mathrm{ml}$ of $15 \%$ ethanol per day), P1 (15\% ethanol and the methanolic extract of coffee skin, or MECS, at the dose of $125 \mathrm{mg} /$ $\mathrm{kg} \mathrm{BW}), \mathrm{P} 2$ (15\% ethanol and MECS $250 \mathrm{mg}$ / $\mathrm{kg} \mathrm{BW}$ ) and P3 (15\% ethanol and MECS 500 $\mathrm{mg} / \mathrm{kg} \mathrm{BW}$ ). Ethanol was administered orally using a $1 \mathrm{ml}$ disposable syringe, then MECS $(1 \mathrm{ml})$ was given in two hours. These treatments were carried out for 15 days (Noradina et al., 2017).

\section{Preparation of Sperm Suspension}

Mice were sacrificed on Day 15 by cervical dislocation and dissected to remove the testicles. Afterward, the cauda epididymis was separated from the testicles, placed on a small petri dish, and cut repeatedly using surgical scissors. The isolated cauda epididymis was then mixed with $1 \mathrm{ml}$ of PBS solution in a petri dish at $37^{\circ} \mathrm{C}$. This suspension was used to observe sperm characteristics, namely sperm count, viability, and morphology (Parhizkar et al., 2013). After the removal of the cauda epididymis, the testicles were washed with $0.9 \% \mathrm{NaCl}$ and fixed using a neutral buffered formalin (BNF 10\%) for histopathological specimens.

\section{Measurement of Sperm Count}

Ten $\mu \mathrm{L}$ of the sperm suspension in $1 \mathrm{~mL}$ of PBS was collected using a micropipette. Drops of samples were dripped on a hemocytometer and observed under a microscope at 400x magnification (Parhizkar et al., 2013). The number of sperm cells was enumerated in five small squares sized $0.04 \mathrm{~mm}^{2}$ within a counting chamber (Setiawan \& Yunianto, 2015). Then, the average number was calculated and inputted to the formula below:

Sperm count $=$ Number of cells/box x $25 \times$ 105 (cells/mL of diluted samples)

\section{Sperm Viability and Morphology Tests}

Sperm viability and morphology were examined using the smear method. Drops of sperm suspension were dripped on a glass slide, allowed to dry with methanol as a fixative solution, washed, and added with three drops of eosin dye for 30 seconds. After the smears were wind-dried, the object glass slide was observed under a light microscope (400x magnification). The $\%$ viability was analyzed by comparing the living and dead sperms, while the morphology examination drew on the category of shape by (Wyrobek et al., 1975), which distinguishes be- 


\section{JURNAL BIDDJATI}

http://journal.uinsgd.ac.id/index.php/biodjati

tween normal and abnormal sperm shapes.

\section{Preparation of Seminiferous Tubules Speci- mens}

For histopathology, seminiferous tubules specimens were prepared using the paraffin technique (Suvarna et al., 2012). This examination employed Hematoxylin-Eosin (HE) staining and microscopic observation at 100x and 400x magnification. The pictures of the specimens were then taken using an OptiLab microscope camera. Parameters observed during the histopathology included spermatogenic cells, lumen area, and the diameter and area of seminiferous tubules (Setiawan \& Yunianto, 2016).

\section{Statistical Analyses}

The laboratory results were statistically processed using the one-way analysis of variance (ANOVA) to determine whether or not and to what extent the methanolic extract of coffee fruit skin affected sperm count, viability, and morphology, lumen area, and the diameter and area of seminiferous tubules in mice fed with ethanol. Afterward, the Least Significant Difference (LSD) and Duncan's tests were performed to identify the degree to which the treatment groups differed significantly from the control ones.

\section{RESULTS AND DISCUSSION}

\section{Phytochemical Properties of the Coffee Fruit Skin Methanolic Extract}

The methanolic extract of coffee fruit skin produced weighed 107.273 grams. Its phytochemical screening included tannins, saponins, alkaloids, and polyphenols detection tests (Table 1). Based on the phytochemical test results (Table 1), it was found that the methanolic extract of coffee fruit skin was positive for phytochemicals acting as antioxidants, namely saponins, tannins, alkaloids, and polyphenols. These compounds can function as a source of antioxidants that can inhibit the oxidative stress caused by ethanol.

Table 1. The phytochemical screening results of the Arabica coffee skin methanolic extract

\begin{tabular}{cc}
\hline Tests & Descriptions \\
\hline Saponins & + \\
Tannins & + \\
Alkaloids & + \\
Phenolics & + \\
\hline
\end{tabular}

\section{Body Weight of the Mice}

Body weight is one of the anthropometric examinations used in determining the basis for calculating drugs and food. In addition, body weight can be used as a parameter that describes body mass. When body weight is under normal conditions, such as good health and a balance between nutritional needs and guaranteed consumption, body Setiawan et al. weight will develop based on age. But when the condition is abnormal/sick, it allows the development of body weight to be accelerated or slowed down (Utami, 2016). Body weight data in this study (Table 2) showed that there were no significant differences $(\mathrm{P}>0.05)$ between groups. This data shows that there is no toxic effect of coffee fruit skin extract on the growth of mice. 


\section{JURNAL BIDDJATI}

http://journal.uinsgd.ac.id/index.php/biodjati

Table 2. The body weights of the test house mice given $15 \%$ ethanol and the methanolic extract of Arabica coffee fruit skin

\begin{tabular}{ccccccc}
\hline \multirow{2}{*}{ Variables } & \multicolumn{5}{c}{ Treatments } \\
\cline { 2 - 6 } & Day & K1 & K2 & P1 & P2 & P3 \\
\hline Body & 0 & $34 \pm 2.65^{\text {ns }}$ & $35 \pm 2.00^{\text {ns }}$ & $34.3 \pm 3.79^{\text {ns }}$ & $36.3 \pm 2.89^{\text {ns }}$ & $38.3 \pm 4.04^{\text {ns }}$ \\
Weights & 6 & $37.7 \pm 3.06^{\text {ns }}$ & $37.7 \pm 2.08^{\text {ns }}$ & $39.7 \pm 5.69^{\text {ns }}$ & $39.3 \pm 4.04^{\text {ns }}$ & $40.7 \pm 2.52^{\text {ns }}$ \\
(in g) & 11 & $41.7 \pm 3.79^{\text {ns }}$ & $39.7 \pm 2.08^{\text {ns }}$ & $42.3 \pm 4.51^{\text {ns }}$ & $43.3 \pm 0.58^{\text {ns }}$ & $39.7 \pm 0.58^{\text {ns }}$ \\
\hline
\end{tabular}

Notes: Numbers are presented in Mean \pm SD. K1: aquadest, no 15\% ethanol, K2: 15\% ethanol, P1: $15 \%$ ethanol and the methanolic extract of coffee skin (MECS) at the dose of $125 \mathrm{mg} / \mathrm{kg} \mathrm{BW}, \mathrm{P} 2: 15 \%$ ethanol and MECS at $250 \mathrm{mg} /$ $\mathrm{kg} \mathrm{BW}, \mathrm{P} 3: 15 \%$ ethanol and MECS at $500 \mathrm{mg} / \mathrm{kg} \mathrm{BW}{ }^{\text {ns }}$ not significant at $\mathrm{P}>0.05$

\section{Sperm Count on Mice}

Sperm count is a measure that determines the characteristics of sperm based on the number of sperm cells produced in seminiferous tubules. The ANOVA revealed that the methanolic extract of Arabica coffee skin significantly improved sperm count in mice with $15 \%$ ethanol-induced sperm damage $(\mathrm{P}<0.05)$ (Table 3). Similarly, Duncan's test results confirmed that treatment P2 (MECS $250 \mathrm{mg} / \mathrm{kg}$ BW) produced a significant improvement in the number of good-quality sperms compared with $\mathrm{K} 2 \quad(15 \%$ ethanol) $(\mathrm{P}<0.05)$. Exposure to acetaldehyde produced from alcohol metabolism in mice interferes with the whole process of sperm formation in the seminiferous tubules, reducing sperm quality (Akang et al., 2011), and decreases the amount of testosterone secreted, leading to failure in the formation and release of spermatids from Sertoli cells. As a result, the concentration of sperm cells in the Sertoli cells increases, stimulating an autoimmune process and phagocytosis of sperm cells that eventually lower the number of mature sperm cells (Malini, 2013).

Table 3. The sperm characteristics of the test house mice given 15\% ethanol and the methanolic extract of Arabica coffee fruit skin

\begin{tabular}{cccccc}
\hline \multirow{2}{*}{$\begin{array}{c}\text { Variable } \\
\text { groups }\end{array}$} & Sperm count & \multicolumn{2}{c}{ Sperm viability } & \multicolumn{2}{c}{ Sperm morphology } \\
\cline { 3 - 5 }$\left(\times 10^{5}\right.$ cells/ml $)$ & Viable (\%) & Non-viable (\%) & Normal (\%) & Abnormal (\%) \\
\hline K1 & $102 \pm 15.67^{\mathrm{b}}$ & $87.88 \pm 0.008^{\mathrm{c}}$ & $12.11 \pm 0.008^{\mathrm{a}}$ & $92.74 \pm 0.05^{\mathrm{c}}$ & $7.26 \pm 0.006^{\mathrm{a}}$ \\
K2 & $62.5 \pm 22.6^{\mathrm{a}}$ & $68.09 \pm 0.40^{\mathrm{a}}$ & $31.9 \pm 0.04^{\mathrm{c}}$ & $88.14 \pm 0.23^{\mathrm{a}}$ & $11.85 \pm 0.24^{\mathrm{b}}$ \\
P1 & $74.7 \pm 3.8^{\mathrm{a}}$ & $73.56 \pm 0.06^{\mathrm{b}}$ & $26.43 \pm 0.005^{\mathrm{b}}$ & $89.64 \pm 0.05^{\mathrm{a}}$ & $10.35 \pm 0.005^{\mathrm{b}}$ \\
P2 & $86.5 \pm 1.73^{\mathrm{ab}}$ & $87.26 \pm 0.05^{\mathrm{c}}$ & $12.73 \pm 0.005^{\mathrm{a}}$ & $93.33 \pm 0.004^{\mathrm{c}}$ & $6.66 \pm 0.000^{\mathrm{a}}$ \\
P3 & $70.9 \pm 3.53^{\mathrm{a}}$ & $76.89 \pm 0.400^{\mathrm{b}}$ & $23.1 \pm 0.04^{\mathrm{b}}$ & $90.90 \pm 0.2^{\mathrm{c}}$ & $9.09 \pm 0.2^{\mathrm{a}}$ \\
\hline
\end{tabular}

Notes: Numbers are presented in Mean \pm SD. K1: aquadest, no 15\% ethanol, K2: 15\% ethanol, P1: 15\% ethanol and the methanolic extract of coffee skin (MECS) at the dose of $125 \mathrm{mg} / \mathrm{kg} \mathrm{BW}, \mathrm{P} 2: 15 \%$ ethanol and MECS at $250 \mathrm{mg} /$ $\mathrm{kg} \mathrm{BW}, \mathrm{P} 3: 15 \%$ ethanol and MECS at $500 \mathrm{mg} / \mathrm{kg} \mathrm{BW}{ }^{\mathrm{a}-\mathrm{c}}$ significant at $\mathrm{P}<0.05$

It is known that flavonoids can increase sperm count by repairing the sperm plasma membrane (Jamalan et al., 2015) and activation of the enzymes catalase and superoxidase dismutase (SOD) (Lara, 2008). Catalase and SOD are types of enzymatic antioxidants that function to protect cell membranes against free radicals. Besides that, alkaloid compounds and saponins are thought to be able to increase leydig cells in the testicular tissue (Siburian, 2009; Hayati, 2010). Leydig cells are known to play a role in producing the hormone testosterone, where testosterone functions in the spermatogenesis process which is very important in determining sperm count (Campbell $\&$ Reece, 2010). It is suspected that the flavonoid in coffee fruit skin can increase the sperm count of mice after being induced by ethanol. 


\section{JURNAL BIDDJATI}

http://journal.uinsgd.ac.id/index.php/biodjati

Treatment P3 (MECS 500 mg/kg BW) showed a significant decrease in sperm count compared with $\mathrm{K} 1$ and $\mathrm{K} 2(\mathrm{P}<0.05)$ (Table $3)$. This reduction is believed to be a product of oxidative stress arising from the administration of $15 \%$ ethanol and the accumulation of high tannin and saponin levels in the methanolic extract of coffee fruit skin, both of which triggered necrosis and damage to plasma membranes in the sperm cells of the test mice. Udoha et al. (2019) research showed that secondary metabolites in Ocimum gratissium leaf extract such as saponins and flavonoids in high doses can trigger the necrosis mechanism in cells.

\section{Sperm Viability on Mice}

Viability is the ability of sperm to survive after released from the male reproductive organs. Based on the ANOVA results, there was a significant difference $(\mathrm{P}<0.05)$ in the sperm viability of mice with ethanol-induced sperm damage before and after the administration of the extract. Duncan's test confirmed that treatment P2 (MECS $250 \mathrm{mg} / \mathrm{kg} \mathrm{BW}$ ) produced viable sperms that were significantly different from K2 (15\% ethanol) (Table 3 ). Such a difference represents an increase in viable sperm count in the K2 group. The most significant increase was shown by treatment P1 (MECS $25 \mathrm{mg} / \mathrm{kg} \mathrm{BW}$ ), followed by P2 (MECS $250 \mathrm{mg} / \mathrm{kg} \mathrm{BW}$ ).

Oxidative stress can cause damage to the fluidity of the sperm cell membrane, disrupting the fertilization with the ovum (Adaramoye \& Akanni, 2015). Such damage is inclined to reduce sperm survival (sperm viability). Phenolic is known to be contained in the skin of the coffee fruit (Table 1). Phenolic compounds are known to be able to inhibit and reduce the oxidation process by free radicals so that the leydig cells are not disturbed. This results in the secretion of the hormone testosterone by leydig cells to run normally (Ayucitra et al., 2011). As is known testosterone has a function in providing nutrients to sperm during the maturation process which determines the number of sperm that can live (Malini, 2013).

\section{Sperm Morphology on Mice}

Sperm morphology tests observe the characteristics of sperm based on the structure of sperm cells. Morphologically, a normal mouse sperm has an elongated head, sharp/ tapered tail that is bent sideways - creating a hook-like shape, and thick/large and quite long neck (Tablado et al., 1998; La Maestra et al., 2015). The ANOVA results showed that various doses of coffee skin extract significantly affected the sperm morphology of mice with ethanol-induced sperm damage $(\mathrm{P}<0.05)$. Similarly, Duncan's test revealed that treatment P2 (MECS $250 \mathrm{mg} / \mathrm{kg} \mathrm{BW}$ ) produced a significant improvement in sperm morphology compared with K2 (15\% ethanol) $(\mathrm{P}<0.05)$. This statistical analysis confirmed that $\mathrm{P} 2$ gave the most favorable results in improving the sperm morphology of the test mice.

Saponins, tannins, phenolics, and alkaloids contained in the skin of the Arabica coffee fruit are known to help reduce the effectiveness of free radicals (Muzdalifa \& Jamal, 2019). This results in the release of follicle-stimulating hormone (FSH) by the anterior pituitary to run normally. Normal FSH release is thought to be able to determine normal sperm morphology. As we know the function of FSH is to stimulate the Sertoli cells in which without this stimulation, the conversion of the spermatids to sperm (the process of spermiogenesis) will not occur. Besides, sertoli cells will secrete a special nutrient fluid that is ejaculated along with the sperm. This fluid contains hormones (testosterone and 


\section{JURNAL BIDDJATI}

http://journal.uinsgd.ac.id/index.php/biodjati

estrogens), enzyme, and special nutrients that are essential for sperm maturation (Guyton \& Hall, 2016).

\section{Histopathology of Testicular on Mice (Seminiferous Tubules)}

Histopathology of seminiferous tubules aimed to determine the extent of damage to spermatogenic cells during spermatogenesis in seminiferous tubules. In this case, the microscopic examination of the testicles proved that in K1 (Figure 1), the seminiferous tubules were still covered with regularly arranged germinal epithelium and surrounded by thin connective tissue (fibrinogen). Also, the lumens-i.e., cavities or hollow structures in seminiferous tubules were densely packed with spermatogenic cells (Figure 1). Meanwhile, treatment $\mathrm{K} 2$ induced the degeneration of spermatogenic cells in seminiferous tubules so that wide lumens and increasingly smaller seminiferous tubules were apparent.

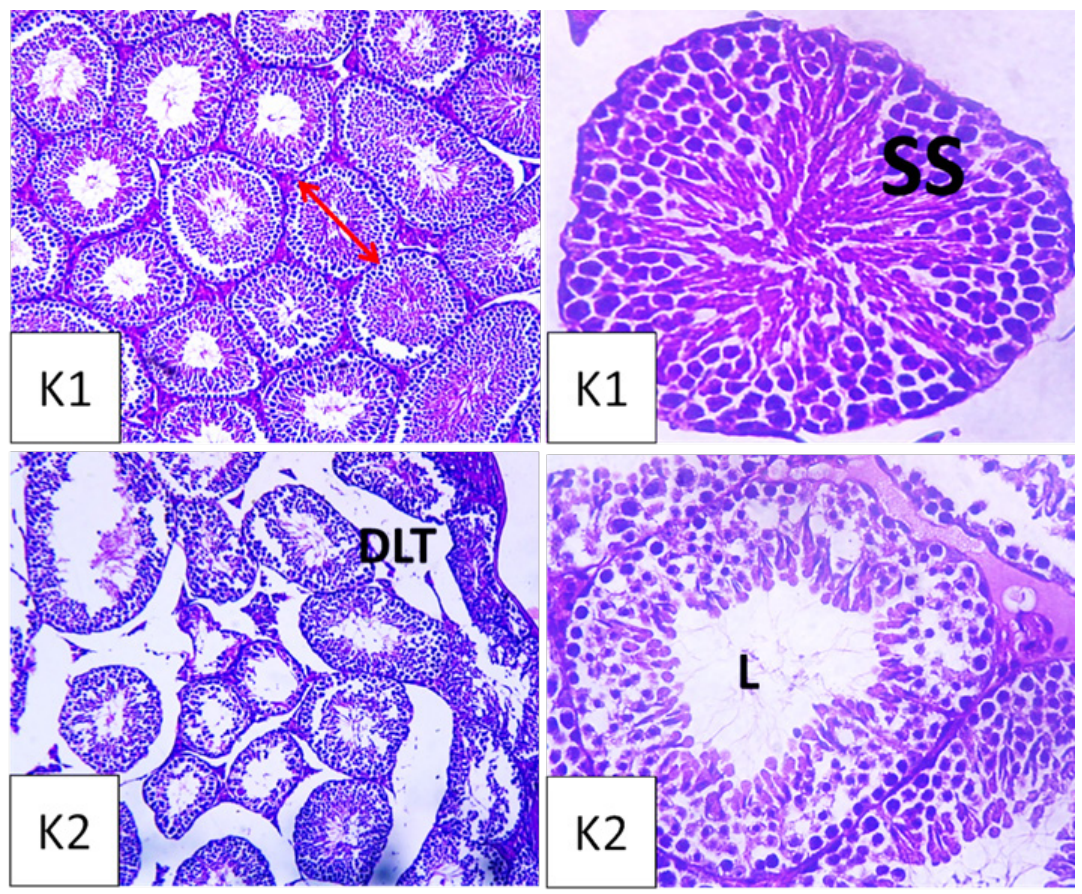

Figure 1. Histopathology of mice testicles in the control groups: K1 (no 15\% ethanol) and K2 (15\% ethanol) at 100x (left) and 400x magnification (right). In K1, seminiferous tubules (arrows) were densely filled with spermatogenic cells (SS), while in K2, dilatation (DLT) in the interstitial tissue and lumen (L) was visible.

Compared to $\mathrm{K} 1$, the microscopic structure of the tissue of seminiferous tubules in K2 showed dilated (DLT) or broadened lumen. In the treatment groups, P1 $(125 \mathrm{mg} / \mathrm{kg}$ $\mathrm{BW})$ and $\mathrm{P} 2(250 \mathrm{mg} / \mathrm{kg} \mathrm{BW})$, the methanolic extract of coffee fruit skin yielded improvements in the structure of the tissue (Figure 2).
In $\mathrm{P} 2$, tissue repairs were visible, as evident from lumens that were densely packed with spermatogenic cells, increased size of seminiferous tubules, and improved epithelial and connective tissues that were nearly similar to the microscopic pictures of tubules in $\mathrm{K} 1$ (Figure 1). 
Jurnal Biodjati 5(2):259-270, November 2020

\section{JURNAL BIDDJATI}

http://journal.uinsgd.ac.id/index.php/biodjati

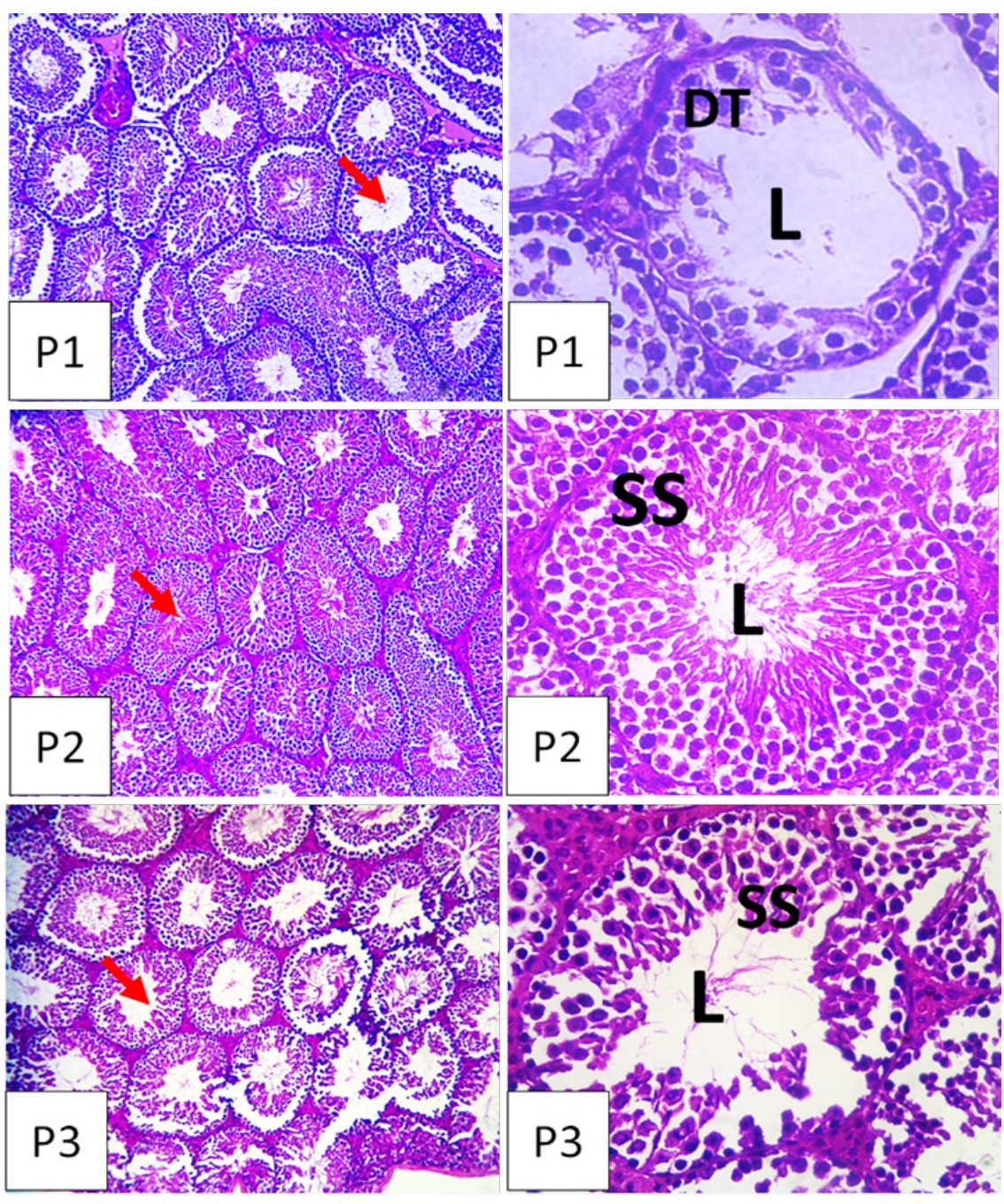

Figure 2. Histopathology of the testicles of mice given $15 \%$ ethanol and the methanolic extract of coffee skin (MECS) at the doses of $125 \mathrm{mg} / \mathrm{kg} \mathrm{BW}$ (P1), $250 \mathrm{mg} / \mathrm{kg} \mathrm{BW}$ (P2), and $500 \mathrm{mg} / \mathrm{kg} \mathrm{BW}$ (P3) at 100x (left) and 400x magnification (right). In P1, the lumen was dilated (DT) but not densely packed with spermatogenic cells. In P2, spermatogenic cells (arrow) started to pack the seminiferous tubules densely and the lumen was filled with spermatozoa (L). In P3, the lumen was not densely packed with spermatogenic cells.

In P3 (500 mg/kg BW), many degenerations of spermatogenic cells in the seminiferous tubules and lumen dilatation were still seen. At this dose, the methanolic extract of Arabica coffee fruit skin contains too high concentrations of secondary metabolites that cause toxicity and cell damage instead. Data on seminiferous tubules were tested using ANOVA, and the results (Table 4) showed that after the sperm damage induction, this extract could significantly affect the area and diameter of seminiferous tubules in mice $(\mathrm{P}<0.05)$. Duncan's test confirmed that compared with $\mathrm{K} 2$, treatment $\mathrm{P} 2$ (250 $\mathrm{mg} / \mathrm{kg} \mathrm{BW}$ ) successfully improved the diameter and area of seminiferous tubules. 


\section{JURNAL BIDDJATI}

http://journal.uinsgd.ac.id/index.php/biodjati

Table 4. The diameter, area, and lumen area of seminiferous tubules of mice given $15 \%$ ethanol and the methanolic extract of Arabica coffee fruit skin

\begin{tabular}{cccc}
\hline $\begin{array}{c}\text { Variable } \\
\text { Groups }\end{array}$ & $\begin{array}{c}\text { Diameters of Seminiferous } \\
\text { Tubules }(\mu \mathrm{m})\end{array}$ & $\begin{array}{c}\text { Areas of Seminiferous } \\
\text { Tubules }\left(\mu \mathrm{m}^{2}\right)\end{array}$ & $\begin{array}{c}\text { Lumen Areas of Seminiferous } \\
\text { Tubules }\left(\mu \mathrm{m}^{2}\right)\end{array}$ \\
\hline K1 & $19.75 \pm 0.39^{\mathrm{c}}$ & $364.17 \pm 14.43^{\mathrm{c}}$ & $41.48 \pm 8.40^{\mathrm{a}}$ \\
K2 & $13.90 \pm 0.46^{\mathrm{a}}$ & $275.19 \pm 27.28^{\mathrm{a}}$ & $80.22 \pm 5.46^{\mathrm{b}}$ \\
P1 & $16.06 \pm 0.25^{\mathrm{b}}$ & $317.90 \pm 19.15^{\mathrm{b}}$ & $72.42 \pm 7.82^{\mathrm{b}}$ \\
P2 & $19.83 \pm 0.90^{\mathrm{c}}$ & $353.14 \pm 8.14^{\mathrm{c}}$ & $39.89 \pm 5.12^{\mathrm{a}}$ \\
P3 & $16.76 \pm 0.05^{\mathrm{b}}$ & $290.79 \pm 4.48^{\mathrm{a}}$ & $70.09 \pm 1.26^{\mathrm{b}}$ \\
\hline
\end{tabular}

Notes: Numbers are presented in Mean \pm SD. K1: aquadest, no 15\% ethanol, K2: 15\% ethanol, P1: $15 \%$ ethanol and the methanolic extract of coffee skin (MECS) at the dose of $125 \mathrm{mg} / \mathrm{kg} \mathrm{BW}, \mathrm{P} 2: 15 \%$ ethanol and MECS at $250 \mathrm{mg} /$ $\mathrm{kg} \mathrm{BW}, \mathrm{P} 3: 15 \%$ ethanol and MECS at $500 \mathrm{mg} / \mathrm{kg} \mathrm{BW}$. ${ }^{\mathrm{a}-\mathrm{c}}$ significant at $\mathrm{P}<0.05$

Based on the ANOVA results (Table 4), the extract could significantly affect the lumen area of seminiferous tubules of the test mice $(\mathrm{P}<0.05)$. The Duncan's test revealed that mice receiving treatment $\mathrm{P} 2(250 \mathrm{mg} /$ $\mathrm{kg}$ BW) had a smaller lumen area compared to the ones receiving $\mathrm{K} 2$ and $\mathrm{P} 1(125 \mathrm{mg} / \mathrm{kg}$ $\mathrm{BW}$ ) and the same area of seminiferous tubules as $\mathrm{K} 1$ (without $15 \%$ ethanol). The data also show that in varying concentrations, the extract could multiply the number of spermatogenic cells that filled the lumen of the seminiferous tubule gradually. The reduced number of spermatogenic cells due to the administration of ethanol 15\% (K1) began to pack the seminiferous tubule and increased as the administered extract concentration was elevated from P1 and P2.

Ethanols damage epithelial tissues that compose seminiferous tubules and, therefore, dilate or broaden the lumen (Martinez et al., 2019). In the test mice, the continuous administration of $15 \%$ ethanol triggered the formation of reactive oxygen species (ROS) in spermatogenic cells. This activity increases the disruption to protein synthesis and simultaneously inactivate the enzyme, resulting in the death of cells (apoptosis) in seminiferous tubules (Aitken et al., 2012). ROS can trigger apoptosis and cell necrosis and suppress spermatogenic cell proliferation; all of which bring about testicular atrophy that shrinks the area and the diameter of seminiferous tubules worsens the degeneration of spermatogenic cells (Dosumu et al., 2014).

The increase in seminiferous tubule diameter is thought to be due to the presence of flavonoids in the skin coffee extract. Based on previous research, the flavonoids in Moringa leaf extract have the ability as antioxidant agents that will protect the testicular cells in the testes from free radicals (Anzila et al., 2017). Besides, flavonoids are able to prevent the formation of ROS by preventing redox reactions that can produce new free radicals (Hardiningtyas et al., 2014). This is thought to affect the HPG axis system so that the release of LH and FSH hormones becomes normal. LH plays a role in stimulating leydig cells to produce testosterone (Guyton, 2016) thus triggering the spermatogenesis process (Sherwood, 2016). This normal hormonal process can lead to the formation of better spermatogenic cells so that the seminiferous tubules appear histologically denser by the spermatogenic cells. This is consistent with research on the provision of basil leaf fractions (Ocimum americanum $\mathrm{L}$ ) containing flavonoids and steroids which are able to improve the diameter of seminiferous tubules (Vinnata et al., 2018). In conclusion, the methanolic extract of coffee fruit skin can improve sperm characteristics and testicular histopathology of mice after the administration of ethanol for 15 days. The 


\section{JURNAL BIDDJATI}

http://journal.uinsgd.ac.id/index.php/biodjati

optimum dose for improving sperm characteristics and testicular tissue is $250 \mathrm{mg} / \mathrm{kg} \mathrm{BW}$.

\section{ACKNOWLEDGEMENTS}

This study received financial assistance form the research fund managed by the Institute for Research and Community Services (LPPM) of Universitas Ahmad Dahlan. The authors declare that there is no conflict of interest with any parties involved in this research.

\section{REFERENCES}

Adaramoye, O. A. \& Akanni, O. O. (2015). Protective Effects of Artocarpus altilis (Moraceae) on Cadmium-induced Changes in Sperm Characteristics and Testicular Oxidative Damage in Rats. Andralogia, 48(2), 152-163.

Aitken, R. J., Jones, K. T. \& Robertson, S. A. (2012). Reactive Oxygen Species and Sperm Function In Sickness and In Health. Journal of Andrology, 33(6): 1096-1106.

Akang, E., Oremosu, A., Dosumu, O. \& Ejiwunmi, A. (2011). Telfairia ocidentalis, a Prophylactic Medicine for Alcohol's Damaging Effect on the Testis. Macedonian Journal of Medicinal Sciences, 4(4), 380-387.

Anzila, I., W M, A. P., Soewondo, A. \& Rahayu, S. (2017). Pengaruh Ekstrak Ethanol Kemangi (Ocimum canum Sims.) terhadap Struktur Histologi Testis Mencit (Mus musculus) Jantan. Biotropika: Journal of Tropical Biology, 5(1), 22-26.

Ayucitra, A., Indraswati, N., Mulyandasari, V., Dengi, Y. K., Francisco, G. \& Yudha, A. (2011). Potensi Senyawa Fenolik Bahan Alam Sebagai Antioksidan
Alami Minyak Goreng Nabati. Jurnal Widya Teknik, 10(1), 1-10.

Campbell, N. A. \& Reece, J. B. (2010). Biologi Jilid 3 Edisi ke 8. Jakarta: Erlangga.

Çeribaşi, A. O., Türk, G., Sönmez, M., Sakin, F. \& Ateşşahin, A. (2010). Toxic Effect of Cyclophosphamide on Sperm Morphology, Testicular Histology and Blood Oxidant-Antioxidant Balance, and Protective Roles of Lycopene and Ellagic Acid. Basic \& Clinical Pharmacology \& Toxicology, 107(3), 730-736.

Cohen, H. K., Kruglick, P. L. M. A. \& Gonzalez, M. D. C. (2003). Effect of Maternal and Paternal Alcohol Consumption on Success Rates of In Vitro Fertilization and Gamete Intrafallopian Transfer. Fertility and Sterility, 79(2), 330-339.

Condorelli, R. A., Calogero, A. E., Vicari, E. \& La Vignera, S. (2015). Chronic Consumption of Alcohol and Sperm Parameters: Our Experience and The Main Evidences. Andrologia, 47, 368-379.

De Souza, B. R., Mathias, L. S,. De Souza, T. L. M. \& Camargo, I. C. C. (2017). Histopathological and Morphometric Evaluation in the Testis and Epididymis of Adult Rats Submitted to a Recovery Period After Treatment with Anabolic Steroid, Alcohol, and/or Nicotine. Journal of Interdisciplinary Histopathology, $0(0), 1-7$.

Dosumu, O. O., Osinubi, A. A. A. \& Duru, D. I. O. (2014). Alcohol Induced Testicular Damage: Can Abstinence Equal Recovery?. Middle East Fertility Socety Journal.

Dungira, S. G., Katja, D. G. \& Kamu, V. S. (2012). Aktivitas Antioksidan Ekstrak Fenolik dari Kulit Buah Manggis (Garcinia mangostana L.). Jurnal Mipa Unsrat Online, 1(1):11-15.

Esquivel, P. \& Jimenez, V. M. (2012). Func- 


\section{JURNAL BIDDJATI}

http://journal.uinsgd.ac.id/index.php/biodjati

tional Properties of Coffe by-products. Food Research International, 46(2), 488-495.

Guyton \& Hall. (2016). Textbook of Medical Physiology Thirteenth Edition. Mississippi: University of Mississippi Medical Center Jackson.

Hardiningtyas, S. D., Purwaningsih, S. \& Handharyani, E. 2014. Aktivitas Antioksidan dan Efek Hepatoprotektif Daun Bakau api-api putih. Jurnal Pengolahan HasilPerikananIndonesia, 17(1), 80-91.

Hayati, F. (2010). Pengaruh Pemberian Ekstrak Pasak Bumi (Eurycoma longifolia J.) Terstandar Terhadap Kualitas Spermatozoa, Profil Testis, dan Hormon Testosteron Tikus Putih Jantan. Disertasi. Yogyakarta: Universitas Gadjah Mada.

Jamalan, M., Ghaffari, M. A., Hoseinzadeh, P., Hashemitabar, M. \& Zeinali, M. (2015). Human Sperm Quality and Metal Toxicants: Protective Effects of some Flavonoids on Male Reproductive Function. Int J Fertil Steril, 9(3): 215-222.

La Maestra, S., De Flora, S. \& Micale, R. T. (2015). Effect of Cigarette Smoke on DNA Damage, Oxidative Stress, and Morphological Alterations in Mouse Testis and Spermatozoa. International Journal of Hygiene and Environmental Health, 218(1), 117-122.

Lara, L. V., Pasqualotto, E. B., Junior, E. B., Braga, D. P. A. F., Salvador, M. \& Pasqualotto, F. F. (2008). Flavonoids May Increase Semen Quality in Infertile Man with Oligospermia?. American Society for Reproductive Medicine, 90, 190-191.

Malini, D. M. (2013). Pengaruh Ekstrak Etanol dan Spinasterol Daun Senggugu (Clerodendron serratum L.) Terhadap Kualitas Sperma Mencit (Mus musculus L.). Journal of Applied Sciences, 3(3),
49-54.

Martinez, M., Maceraa, S., De A, Pinheiro, P.F.F., Almeida, B., Tirapelli, C., Martins, O., Mello, W., Padovani, D. \& Martinez, F. (2019). Structural Evaluation of the Effects of Chronic Ethanol Ingestion on the Testes. Tissue and Cell, 41(3), 199-205.

Meriani, H. (2017). Pengaruh Pemberian Vitamin E Terhadap Jumlah Sel Sperma Mencit (Mus musculus L.) yang Dipapar Tuak. Jurnal Keperawatan Imelda, 3(1), 919-200.

Muzdalifa, D. \& Jamal, S. (2019). Uji Aktivitas Antioksidan Ekstrak Fraksi Kulit Biji Kopi Robusta (Coffea canephora Pierre ex A. Froehner) terhadap Pereaksi DPPH (1,1- Difenil-2-Prikihildrazil). Indonesia Natural Research Pharmaeutical Journal, 6(2), 41-50.

Parhizkar, S., Yusoff, M. J. \& Dollah, M. A., (2013). Effect of Phaleria macrocarpa on Sperm Characteristics in Adult Rats. Advanced Pharmaceutical Bulletin, 3(2), 345-352.

Setiawan, H. \& Yunianto, I. (2015). Aktivitas Ekstrak Etanol daun Jambu Mete (Anacardium occidentale L.) terhadap Mencit (Mus musculus L.) sebagai Materi Pembelajaran Siswa SMA Kelas XI IPA untuk Mencapai KD 3.12 Kurikulum 2013. Jupemasi-PBio, 1(2), 212218.

Setiawan, H. \& Yunianto, I. (2016). Pengaruh Ekstrak Etanol Daun Jambu Mete (Anacardium occidentale L.) terhadap Perkembangan Sel Spermatogenik Mencit (Mus musculus L.). Prosiding Symbion. 405-416.

Siburian, J. \& Marlinza, R. (2009). Efek Pemberian Ekstrak Akar Pasak Bumi (Eurycoma longifolia J.) Pada Tahap Prakopulasi Terhadap Fertilitas Mencit 


\section{JURNAL BIDDJATI}

http://journal.uinsgd.ac.id/index.php/biodjati

(Mus musculus L.) Betina. Jurnal Biospesies, 2(2), 24-30.

Suvarna, S. K., Layton, C. \& Bancroft, J. D. (2012). Bancrofts Theory and Practice of Histological Techniques. United Kingdom: Elsevier.

Tablado, L., Pérez-Sánchez, F., Núñez, J., Núñez, M. \& Soler, C. (1998). Effects of Exposure to Static Magnetic Fields on the Morphology and Morphometry of Mouse Epididymal Sperm. Bioelectromagnetics, 19(6), 377-383.

Udoha, M. U., Okolie, N. J. \& Ijioma, S. N. (2019). Chronic Oral Administration of Ocimum gratissimum Leaf Extract Induced Gastrointestinal Necrosis in Treated Albino Rats. European Journal of Medical Plants, 27(3), 1-9.
Utami, N. W. A. (2016). Modul Antropometri. Bali: Fakultas Kedokteran Universitas Udayana.

Vinnata, N. N., Salni. \& Nita, S. (2018). Pemberian Fraksi Daun Kemangi (Ocimum americanum L.) terhadap Spermatozoa Tikus Putih Jantan (Rattus norvegicus). Jurnal Kesehatan, 9(3), 366-375.

Wael, S. \& Mahulette, F. (2013). Pengaruh Pemberian Minuman Tradisional Arak Ambon (Sopi) Terhadap Spermatozoa Tikus Sprague Dawley. Bimafika, 4(2), 495-498.

Wyrobek. A. J., \& Bruce, W. R. (1975). Chemical Induction of Sperm Abnormalities in Mice. Cell Biology, 72(11), 4425-4429. 